\title{
Improving Student's Critical Thinking Ability Through Guided Discovery Learning Methods Assisted by Geogebra
}

\author{
Ismail Hanif Batubara \\ Department of Mathematics Education, Faculty of Teacher Training and Education, University of Muhammadiyah Sumatera Utara, Indonesia \\ ismailhanif@umsu.ac.id \\ *Corresponding Author \\ Whatsapp Number : [+62-85370552283]
}

How to Cite : Batubara, I., H., (2019). Improving Student's Critical Thinking Ability Through Guided Discovery Learning Methods Assisted by Geogebra. International Journal for Educational and Vocational Studies, 1 (2), 116-119.

\section{ARTICLE HISTORY}

Received:3 May 2019

Revised: 23 May2019

Accepted: 29 May 2019

\section{KEYWORDS}

Critical Thinking;

Guided Discovery Learning;

Geogebra;

\section{ABSTRACT}

This research is aimed to know: (1) Whether the increasing student's critical thinking ability through guided discovery learning methods assisted by geogebra higher than the students who were given guided discovery methods without geogebra, (2) How the interaction between learning and early math ability of student mathematical learning result. This study was a quasi-experimental study. The population of this study was the entire class of six semester mathematics education which approximately 184 people. Randomly, two classes were selected from six classes. The first experimental class was given a geogebra assisted discovery method and the second experimental class was given a guided discovery method without geogebra . The instrument used was a description test. The data analysis has been done by analysis of two-way variance (ANOVA). The results showed (1) the increasing student's critical thinking ability through guided discovery learning methods assisted by geogebra were better than the students who were given guided discovery learning methods without geogebra. (2) There was no Interaction between learning and early math ability of student mathematical learning results.

This is an open access article under the CC-BY-SA license

\section{INTRODUCTION}

Some of mathematical material becomes a necessity that cannot be negotiated in the arrangement of reason and decision making. In accordance with the graduate profile of the UMSU mathematics education study program, it was stated that graduates of mathematics education should be able to become educators and educate and also learn mathematics at elementary and secondary education levels. But unfortunately there are still many students who do not master the material in the subject of education, which is an educational material in schools.

For example, many students are unable to describe a graph of the function given. Not to mention other materials such as integrals, ranks and series and so on, there are still many students who are still hesitant and uncertain in completing and determining solutions to the problems that arise. Even though to be a teacher, the material above must be mastered by someone who holds a profession as a teacher. The lack of understanding of students' concepts on the material is a separate dilemma for students. Shamrock (Irawati, 2014: 208) states that understanding concepts and also critical thinking is a key aspect of learning, one of the important teaching objectives is to help students understand the main concepts in a subject rather than just remembering separate facts. The discrepancy between the facts and what is expected today is the background of the author in writing this research report.

The application of guided discovery learning is one of the solutions to the above problems. Shadiq (2009: 12) explains that guided discovery learning is a learning where students are given a situation or problem, which then performs data collection, making guesses (conjectures), trial and error, searching and finding order (patterns), generalizing or composing formulas and general forms, proves the correctness of the allegations. Therefore guided learning discovery enables students to build their own knowledge through activities designed, so as to make a conclusion based on critical thinking.

ICT assistance such as Geogebra software can also attract students' interest in learning mathematics. Karnasih (2008) also said that "Geogebra lead the way in use of dependent, selectable mathematics objects to help students get to grip with the principles of probability and 
statistics, graph, coordinate geometry, in both $2 \mathrm{D}$ and 3D". The expert's opinion explained that Geogebras can help students to understand learning materials such as probability, statistics, and geometry because the Geogebra has 2D and 3D worksheets. Thus it can be concluded that the use of Geogebra software can help educators and students in the process of learning and learning in school.

Based on the above problems, as well as several solutions mentioned earlier, the researchers tried to combine guided discovery learning with computer technology (Geogebra) media, to improve the ability of critical thinking mathematics. This research is aimed to know(1) Whether the increasing student's critical thinking ability through guided discovery learning methods assisted by geogebra higher than the students who were given guided discovery methods without geogebra, (2) How the interaction between learning and early math ability of student mathematical learning result. This study was a quasi-experimental study.

\section{METHODS}

Materials are focus on integral reaman to find out surface area and how to make it in curve.

$$
\int_{a}^{b} f(x) d x=[F(x)]_{a}^{b}=F(b)-F(a)
$$

The population of this research was all sixth semester of mathematics education approximately 184 peoples. While the sample in this study were two classes selected from the existing classes in the sixth semester of mathematics education, Faculty of Teacher training and education, University of Muhammadiyah Sumatera Utara, Indonesia.

This research is a quasi-experimental research. This research was carried out with geogebra-assisted guided discovery method. Broadly speaking, it was concluded that this study was carried out in stages: (1) Stage of preparation of learning tools and research instruments which included initial tests and so on (2) The experimental implementation stage in the form of learning treatment, and (3) Analysis phase of research results. Each stage is designed so that valid data is obtained in accordance with the characteristics of variables and research objectives. Data collected in this study was data relating to student learning outcomes taken using the test. The test is done by giving essay questions. The test was given in the form of pretest and posttest questions.

\subsection{Statistical Data Analysis}

Data of Analysis of Variance (ANOVA) and means comparison was computed by $\mathrm{R}$ software. DMRT test was used to analyze significant different in different level of treatment with probability 5\%. Data analyzed begin with testing the statistical requirements needed as a basis for testing hypotheses, including the normality of the data and homogeneity of variance. Furthermore, the test, regression and correlation are adjusted according to the problem. All statistical calculations in this study used the helping of SPSS 16.

To test the first hypothesis increased ability to increasing critical thinking ability, we used:

$$
\begin{aligned}
& \mathrm{H}_{0}: \mu_{x}=\mu_{y} \\
& \mathrm{H}_{\mathrm{a}}: \mu_{x} \neq \mu_{y}
\end{aligned}
$$

To examine the second hypothesis is interaction between learning and the students, we used:

$$
\mathrm{H}_{0}: \quad \mu_{11}-\mu_{12}=\mu_{21}-\mu_{22}=\mu_{31}-\mu_{32}
$$

$H_{a}$ : There is at least one difference in the average ability to critical thinking mathematic's ability that are different from the others.

\section{RESULTS AND DISCUSSION}

\subsection{The First Hypothesis}

To test the increased of critical thinking ability is shown on table below : 
Table 1: Independent Samples Test

\begin{tabular}{|c|c|c|c|c|c|c|c|c|c|c|}
\hline & & \multicolumn{4}{|c|}{$\begin{array}{c}\text { Levine's Test for Equality of } \\
\text { Variances }\end{array}$} & \multicolumn{5}{|c|}{ t-test for Equality of Means } \\
\hline & & $\mathrm{F}$ & Sig. & $\mathrm{t}$ & df & $\begin{array}{l}\text { Sig. } \\
(2- \\
\text { tailed) }\end{array}$ & $\begin{array}{c}\text { Mean } \\
\text { Differe } \\
\text { nce }\end{array}$ & \begin{tabular}{|l|} 
Std. \\
Error \\
Differen \\
ce
\end{tabular} & $95 \% \mathrm{C}$ & $\begin{array}{l}\text { nce Interval of } \\
\text { fference }\end{array}$ \\
\hline & & & & & & & & & Lower & Upper \\
\hline $\begin{array}{l}\text { Critical thinking } \\
\text { Mathematic }\end{array}$ & $\begin{array}{c}\text { Equal variances } \\
\text { assumed } \\
\text { Equal variances not } \\
\text { assumed }\end{array}$ & .056 & .814 & $\begin{array}{c}3.55 \\
4 \\
\\
3.55 \\
4\end{array}$ & 58 & $\begin{array}{l}.001 \\
.001\end{array}$ & $\begin{array}{r}.13100 \\
.13100\end{array}$ & $\begin{array}{l}.03686 \\
.03686\end{array}$ & $\begin{array}{l}.05721 \\
.05720\end{array}$ & .20479 \\
\hline
\end{tabular}

Based on the table's results of calculations using the $t$ test at a significance level $\alpha=0.05$ obtained $t$ count of 3.554 with a significance value of 0.184 while the $t$ table is 1.99. Because of $t$ count $>t$ table $(3.554>1.99)$ and significance value $0.014<0.05$, so $\mathrm{HO}$ is rejected. So it can be concluded that the improvement of Critical Thinking ability of students taught by guided discovery learning methods assisted geogebra are higher than taught by guided discovery learning methods without geogebra.

\subsection{The Second Hypothesis}

The interaction between learning and the students mathematical is shown on table below.

Table 2. Tests of Between-Subjects Effects

Dependent Variable: gain

\begin{tabular}{|l|r|r|r|r|r|}
\hline Source & $\begin{array}{r}\text { Type III } \\
\text { Sum of } \\
\text { Squares }\end{array}$ & df & $\begin{array}{r}\text { Mean } \\
\text { Square }\end{array}$ & \multicolumn{1}{|c|}{$\mathrm{F}$} & \multicolumn{1}{c|}{ Sig. } \\
\hline Corrected & $.864 \mathrm{a}$ & 5 & .173 & 16.226 & .000 \\
Model & 28.006 & 1 & 28.006 & $2.629 \mathrm{E} 3$ & .000 \\
Intercept & .291 & 1 & .291 & 27.315 & .000 \\
Learning & .539 & 2 & .269 & 25.288 & .000 \\
KAM & .058 & 2 & .029 & 2.737 & .074 \\
Learning & .575 & 54 & .011 & & \\
KAM & 33.224 & 60 & & & \\
Error & 1.440 & 59 & & & \\
Total & & & & \\
Corrected & & & & \\
Total & & & & \\
\hline
\end{tabular}

a. $\mathrm{R}$ Squared $=, 600$ (Adjusted $\mathrm{R}$ Squared

$=, 563$ )

Based on the table above shows that for learning factors and KAM (Early Mathematical Abilities), obtained a significance value of 0.74 . Because the significance value is greater than 0.05 significance level, Ho is accepted, which means that there is no interaction between the learning approach and the students' ability to improve students' critical thinking. So, increasing the ability to understand student's critical thinking is caused by differences in learning used not because of students' mathematical abilities. In other words, there is no shared influence given by learning and KAM.

Seeing the results of the research presented above, shows that guided discovery learning methods assisted by Geogebra are significantly better in improving student learning outcomes compared to guided discovery methods without Geogebra. In this learning activity students have the opportunity to interact with their communities. Students will share ideas to propose solutions both in groups and present their final results in front of the class. So that students can easily find errors in solving problems that are made. Whereas for high-ability students have the opportunity to practice conveying ideas and ideas to others and respect the opinions of others so that it is possible to increase their knowledge.

But the second experimental class that happened was not as expected. Most students do not make maximum efforts to use all their cognitive abilities, and do not interact with their communities and attach importance to their respective egos. So that students work individually when solving problems. Besides students attaching importance to each other's ego, other students depend on the lecturer to solve the problem, so the repetitive and memorizing nature of repetition as the formation of knowledge with the lecturer as a model and source of learning also occurs in this class. Thus, the active role of students and the interactions that occur are minimal.

The thing that makes no interaction between learning and the level of students ' mathematical ability to improve student learning outcomes is the relatively similar learning giving factor between the two classes so that the students' mathematical abilities do not influence simultaneously on improving student learning outcomes.

Based on finding, it can be concluded that the use of guided discovery learning methods assisted by Geogebra 
is better than the guided discovery method without Geogebra. These findings are in line with research conducted by Afriati, V. (2011), which states that students who get guided findings assisted by Geogebra software show more learning effectiveness than students who get the usual approach. Batubara, IH (2017: 103) states that the improvement of students' critical thinking skills taught through Geogebra-assisted problem-based learning is higher than those taught through geogebraassisted problem-based learning.

\section{CONCLUSION}

Based on the results of the data analysis above, there are some conclusions which are the answer of problem's formulation, including:

1. The increasing of critical thinking ability through guided discovery learning methods assisted by Geogebra higher than the students who were given guided discovery methods without Geogebra

2. There is no interaction between learning and early math ability of student mathematical learning result

3. To improve student learning outcomes, educators can use guided discovery methods with Geogebra software as an alternative.

4. In each learning educator must create a learning atmosphere that provides opportunities for students to express mathematical ideas in their own language and ways, so that the students become brave to argue, more confident, and creative.

\section{REFERENCES}

Afriati, V. (2011). Improving Understanding of Concept and Student Mathematical Communication with the Geogebra Assisted Assisted Discovery Approach. Paradigms Journal, 5 (1 \& 2).

Batubara, IH. (2017). Increased Ability to Understand Mathematical Concepts Through Geogebra and Geogebra-Assisted Problem-Based Learning Models at Free Methodist Medan. Journal of Mathematics Education and Science. Volume (3) 47-54.

Karnasih, Ida. (2008). Paper Presented in International Workshop: "ICT for Teaching and Learning Mathematics". Medan: UNIMED.

Irawati, H. (2014). "Effect of Guided Discovery Learning on Students' Mathematical Understanding Ability". Proceedings of the National Seminar on PostGraduate Mathematics Education Program STKIP Siliwangi Bandung. Volume 1 ISSN 2355-0473.

Shadiq, F. (2009). "Junior High School Mathematics Learning Models". Yogyakarta: Ministry of National Education's P4TK Mathematics. 